\title{
Post-War Planning in Nigeria
}

A SPECrAL branch has been set up in the Nigerian Government Secretariat to deal with postwar planning and reconstruction. Mr. F. E. V. Smith, who is at present Commissioner of Commerce and Industries in Jamaica, is to be in charge. Mr. J. N. Oliphant, C.M.G., M.B.E., who has been appointed to advise the new branch on rural development, was Chief Conservator of Forests from 1939 to 1943 in Nigeria. In the January issue of the Crown Colonist Mr. Oliphant argues the case for planning and control of land use, and for a policy directed to the conservation of soil and vegetation. He is strongly opposed to schemes which involve exhaustion without replacement of natural resources. "That most important of all natural resources', he writes, 'the soil, must be kept in good heart and the fertility of the land maintained; water supply and climactic amenities must be conserved; forest that is cut must be replanted or regenerated. ...' The Nigerian Forest department has for some time strongly advocated the need for the planning and control of land use. It is now clear that the stage has been reached where a general campaign by all the rural Departments, co-ordinated by the Administrative Service, is needed. Mr. Oliphant points out that in the training of forest staff at the Forest School in Ibadan, land use studies are already included, and that the forest staff could help in the enforcement of regulations directed against the misuse of land; he also reports that the reaction of the more progressive Native Authorities to early efforts in rural planning has bẹen definitely encouraging.

\section{Uganda's Weaving Industry}

THE development of the weaving industry in Uganda is noted in The African World of 25 March 1944. New spinning apparatus is being designed to speed up the development of the spinning and weaving industry. The textile workshops, run by the Uganda Industrial Committee, have now been working for rather more than a year and have trained more than 400 African workers. The trained spinners and weavers are being encouraged to return to their own villages in order to spread the industry, and three new instruction centres have already been set up. The largest buyers of the workshops' output during the year have been the Polish camps in Uganda, which purchased $£ 460$ worth of woven goods.

\section{An African Linguist}

WE are very happy to note the recent award of the M.B.E. to Mr. C. A. Akrofi, whose valuable work on the Twi and Akan languages is no doubt well-known to many of the readers of Africa. Mr. Akrofi, who taught for twenty years in the Presbyterian Training College at Akropong, has made an extensive study of the Akan language which, with varying dialects, is spoken by some 800,000 to 1,000,000 people over a wide area in the Gold Coast and Ashanti. In addition to his Grammar of Twi and Twi Spelling Book, written for use in Gołd Coast schools, Mr. Akrofi has supervised and edited a number of other books, of which Dr. Ida Ward writes: 'In number and quality these publications rank high among vernacular work in any part of Africa, and if literary activity is spreading in the area, some at least of the credit is due to Mr. Akrofi, either because of his direct encouragement, or by the very fact of his having devoted a life-time to its study.... The award of this honour is a sign of the importance of vernacular studies in Africa, and is particularly to be welcomed at this moment when adult and mass education plans are to be put into action,' 